\title{
JURNAL
}

\section{Analisis Kekuatan Stabilizer Bar (Anti-Roll Bar) Pada Kendaraan Roda Empat Menggunakan Bantuan Software Solidworks}

\author{
Iwan Agustiawan dan Ardi Adhiguna Riyadhi \\ Teknik Mesin Institut Teknologi Nasional Bandung, Indonesia \\ Jl. PKH. Mustapha No. 23, Bandung 40124 \\ e-mail : gusti@itenas.ac.id
}

\begin{abstract}
Abstrak
Stabilizer bar berfungsi mengurangi besarnya sudut rolling, sehingga diharapkan kendaraan lebih stabil. Tujuan yang ingin dicapai dari penelitian ini adalah mengetahui kekuatan stabilizer bar akibat body roll kendaraan dengan pemodelan dan simulasi serta analisis menggunakan bantuan software solidworks. Metode yang digunakan adalah mengidentifikasi karakteristik fisik, beban, tumpuan dan material yang digunakan untuk proses pemodelan serta simulasi sederhana menggunakan software solidworks sehingga dapat memperoleh tegangan geser dan faktor keamanan. Sebagai pembanding terhadap model dan simulasi solidwork, tegangan geser maksimum yang terjadi dihitung secara manual berdasarkan momen puntir dan momen lentur yang bekerja secara simultan dalam stabilizer bar. Hasil penelitian ini menunjukkan bahwa ketika kendaraan mengalami body roll sebesar 3,51 ${ }^{\circ}$ dimana stabilizer bar terpuntir $2,62^{\circ}$ dan mengalami tegangan geser dan faktor keamanan dari perhitungan manual, yaitu 52,47 MPa dan 9,39 untuk beban statis, 104,94 MPa dan 4,69 untuk beban dinamis. Berdasarkan analisis menggunakan software solidwork tegangan geser dan faktor keamanan, yaitu 50,05 MPa dan 8,96 untuk kondisi statis, 100,1 MPa dan 4,48 untuk kondisi dinamis. Berdasarkan prediksi menggunakan persamaan regresi linier, maka sudut body roll kritis yang dapat dicapai adalah sebesar $45,99^{\circ}$ ketika stabilizer bar mulai mengalami deformasi plastis.
\end{abstract}

Kata kunci : Stabilizer Bar, Anti-Roll Bar, Solidworks

\section{Abstract}

The stabilizer bar functions to reduce the amount of rolling angle, so that the vehicle is expected to be more stable. The purpose of this research is to determine the strength of the stabilizer bar due to vehicle body roll by modeling and simulation and analysis using Solidworks software. The method used is to identify the physical characteristics, loads, supports and materials used for the modeling process and simple simulations using solidworks software so as to obtain shear stress and safety factors. As a comparison to the solidwork model and simulation, the maximum shear stress that occurs is calculated manually based on the torsional moment and the bending moment that work simultaneously in the stabilizer bar. The results of this study indicate that when the vehicle experiences a body roll of $3.51^{\circ}$ where the stabilizer bar is twisted $2.62^{\circ}$ and experiences shear stress and safety factors from manual calculations, namely $52.47 \mathrm{MPa}$ and 9.39 for static loads, $104.94 \mathrm{MPa}$ and 4.69 for dynamic loads. Based on the analysis using solidwork shear stress software and safety factors, namely $50.05 \mathrm{MPa}$ and 8.96 for static conditions, $100.1 \mathrm{MPa}$ and 4.48 for dynamic conditions. Based on predictions using linear regression equations, the critical body roll angle that can be achieved is $45.99^{\circ}$ when the stabilizer bar begins to undergo plastic deformation.

Keywords : Stabilizer Bar, Anti-Roll Bar, Solidworks 


\section{Pendahuluan}

Salah satu parameter yang harus diperhatikan untuk meningkatkan handling performance kendaraan yaitu sudut rolling yang terjadi ketika kendaraan berbelok. Dengan memperkecil sudut rolling tersebut, maka handling performance kendaraan akan meningkat [1] Body roll merupakan fenomena yang terjadi pada sebuah mobil yang bermanuver [2]. Saat paling rawan adalah waktu mobil berbelok dengan kecepatan tinggi dimana kendaraan akan mengalami gejala guling (rolling) yang disebabkan gaya sentrifugal pada kendaraan. Gaya sentrifugal pada kendaraan akan memberi gaya keluar dari pusat titik belok [3]. Hal ini menyebabkan body kendaraan mengalami rolling (body roll). Salah satu faktor yang dikembangkan dalam peningkatan stabilitas kendaraan adalah dengan modifikasi pada sistem suspensi seperti penambahan stabilizer bar [4]. Stabilizer bar berfungsi mengurangi besarnya sudut rolling, sehingga diharapkan kendaraan lebih stabil. Sudut rolling pada kendaraan akan membuat roda memiliki ketinggian yang tidak sama dan menyebabkan stabilizer bar menerima beban puntir. Oleh karena itu dibutuhkan analisis untuk mengetahui kekuatan stabilizer bar akibat body roll kendaraan dengan pemodelan dan simulasi serta analisis menggunakan bantuan software solidworks.

Tujuan dari penelitian ini adalah mengetahui kekuatan stabilizer bar akibat body roll kendaraan dengan pemodelan dan simulasi menggunakan bantuan software solidworks. Perlu dipastikan apa pengaruh body roll terhadap stabalizer bar. Untuk memastikan hal tersebut maka perlu dipahami terlebih dahulu prinsip kerja serta konstruksi stabilizer bar ketika terpasang pada kendaraan, dan perlu dicek tegangan dan deformasi yang terjadi pada stabilizer bar.

Penelitian ini difokuskan untuk mengetahui kekuatan stabilizer bar. Pemodelan berdasarkan kendaraan tertentu yang menerapkan stabilizer bar pada roda bagian depan atau belakang. Mengukur variabel-varibel stabilizer bar meliputi konstruksi dan kekuatan momen puntir. Body roll kendaraan disebabkan oleh kondisi kendaraan yang sedang diganjal salah satu sisi roda oleh beberapa papan kayu.

\section{Metodologi Penelitian}

Metode yang digunakan dalam penelitian adalah metode experimental, dengan melakukan pengujian sederhana pada kendaraan yang menggunakan stabilizer bar pada roda depan atau belakang, dimana salah satu sisi roda diganjal oleh beberapa papan kayu sehingga roda memiliki ketinggian yang berbeda dan kendaraan mengalami fenomena body roll statis. Secara garis besar dilakukan tahapan penelitian mengikuti diagram alir yang ditunjukan pada Gambar 1 sebagai berikut: 


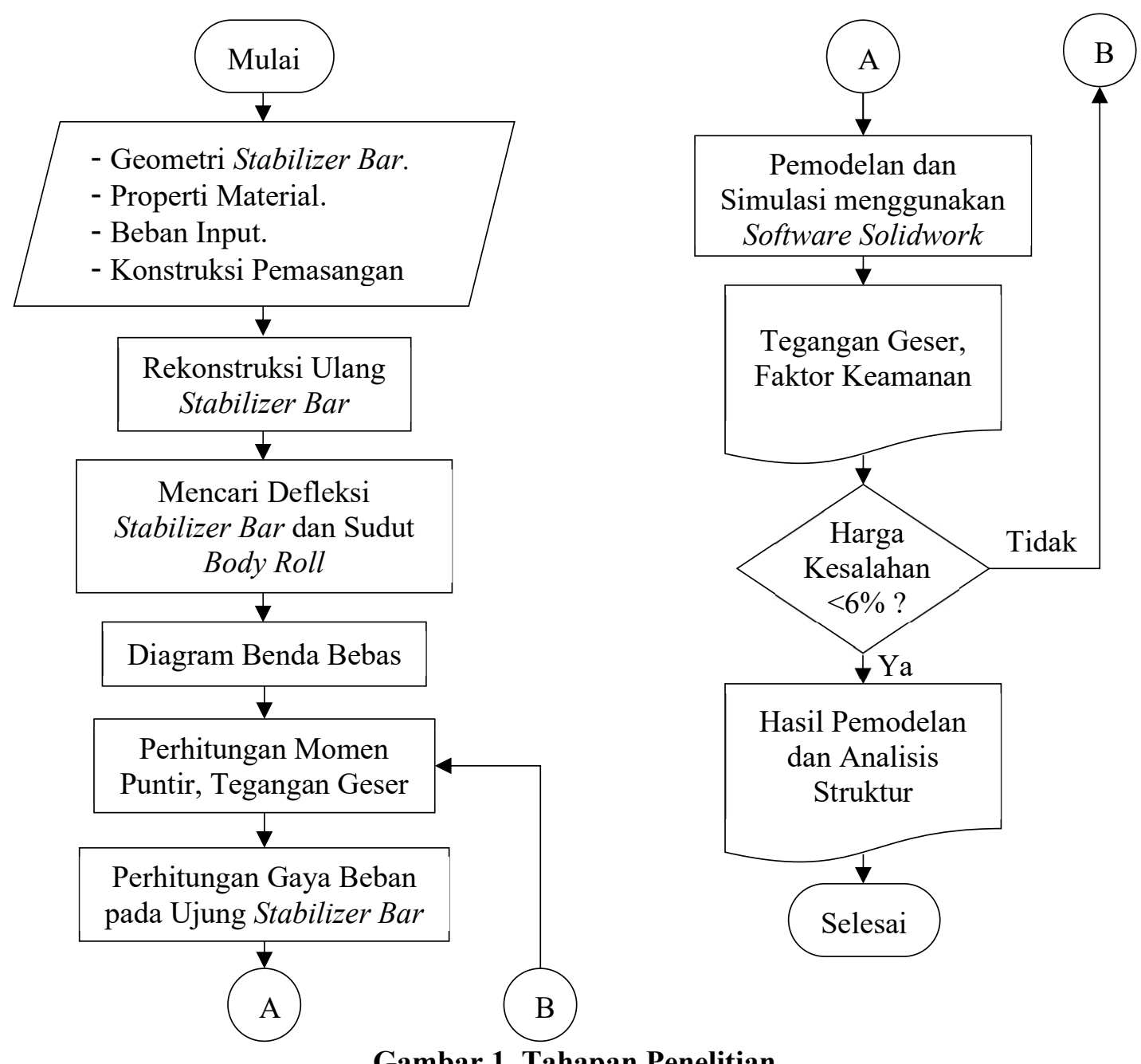

Gambar 1. Tahapan Penelitian

Langkah pertama adalah mengukur geometri stabilizer bar, material yang digunakan, beban yang diterima stabilizer bar, dan konstruksi stabilizer bar saat terpasang, lalu akan dilakukan rekonstruksi stabilizer bar menggunakan software solidworks. Langkah selanjutnya dilakukan pengujian sederhana untuk mengetahui beban input berupa defleksi pada ujung stabilizer bar dan sudut body roll pada stabilizer bar yang akan digunakan untuk pembuatan diagram benda bebas stabilizer bar berdasarkan kondisi pembebanan nyata seperti yang telah dijelaksan. Pada langkah berikutnya melakukan perhitungan manual momen puntir, tegangan geser, dan gaya yang terjadi pada ujung stabilizer bar, dimana parameter tersebut akan diaplikasikan untuk metode numerik fenite element analysis (FEA) menggunakan software solidwork simulation.

\section{Hasil dan Pembahasan}

Sebelum melakukan perhitungan secara manual serta pemodelan tegangan geser dan faktor keamanan menggunakan software solidworks, terlebih dahulu dilakukan proses rekonstruksi stabilizer bar berkaitan dengan sudut body roll kendaraan dan sudut puntir stabilizer bar. Gambar 2 memperlihatkan konstruksi stabilizer bar yang terpasang pada kendaraan. Berdasarkan gambar 2 , kemudian dilakukan pengukuran posisi titik-titik yang ditentukan pada stabilizer bar (terdapat 18 titik pengukuran posisi) yang hasilnya ditunjukkan pada Gambar 3 dan Tabel 1. 


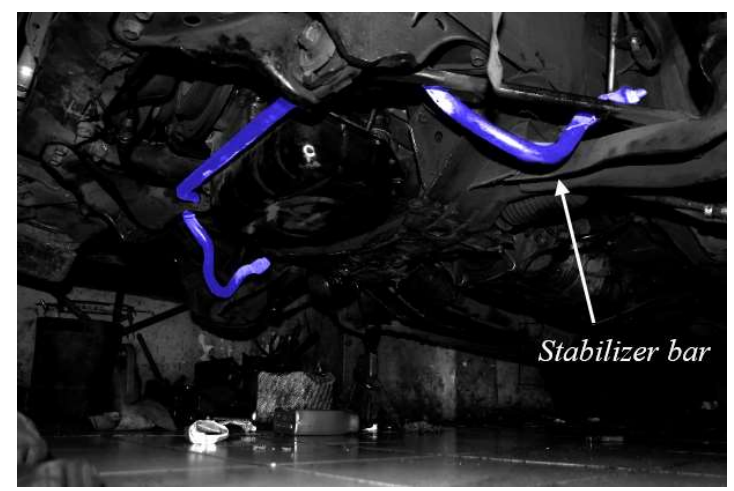

\section{Gambar 2. Konstruksi Stabilizer Bar Yang Terpasang Pada Kendaraan}

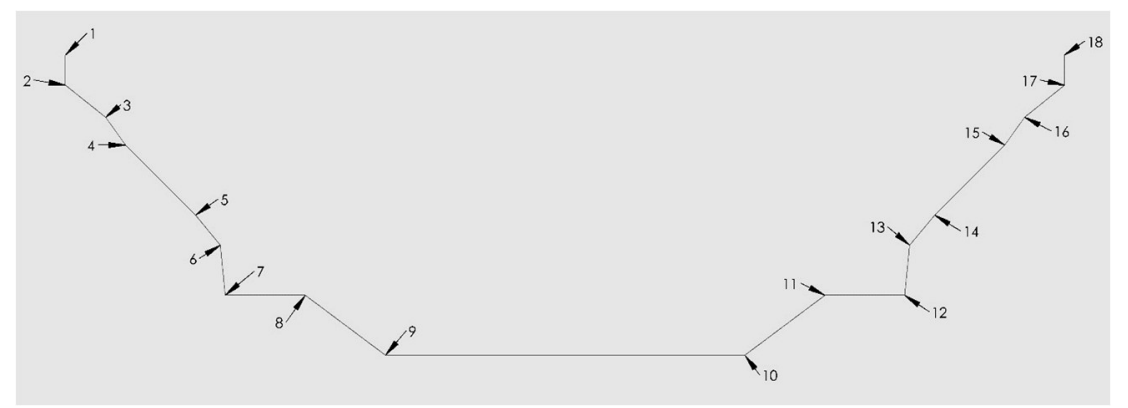

Gambar 3. Titik-titik Pengukuran Posisi Pada Stabilizer Bar

Tabel 1. Data Posisi Titik-titik Pada Stabilizer Bar

\begin{tabular}{cccccccccc}
\hline & $\mathrm{x}(\mathrm{mm})$ & $\mathrm{y}(\mathrm{mm})$ & $\mathrm{z}(\mathrm{mm})$ & $\mathrm{r}(\mathrm{mm})$ & $\mathrm{x}(\mathrm{mm})$ & $\mathrm{y}(\mathrm{mm})$ & $\mathrm{z}(\mathrm{mm})$ & $\mathrm{r}(\mathrm{mm})$ \\
\hline 1 & 0 & 0 & 0 & 0 & 10 & 680 & -200 & 300 & 35 \\
\hline 2 & 0 & -200 & 30 & 15 & 11 & 760 & 0 & 240 & 15 \\
\hline 3 & 40 & -350 & 62 & 15 & 12 & 840 & 0 & 240 & 20 \\
\hline 4 & 60 & -1100 & 90 & 35 & 13 & 845 & -240 & 190 & 30 \\
\hline 5 & 130 & -780 & 160 & 50 & 14 & 870 & -780 & 160 & 50 \\
\hline 6 & 155 & -240 & 190 & 30 & 15 & 940 & -1100 & 90 & 35 \\
\hline 7 & 160 & 0 & 240 & 20 & 16 & 960 & -350 & 62 & 15 \\
\hline 8 & 240 & 0 & 240 & 15 & 17 & 1000 & -200 & 30 & 15 \\
\hline 9 & 320 & -200 & 300 & 35 & 18 & 1000 & 0 & 0 & 0 \\
\hline
\end{tabular}

Catatan: $r=$ radius lekukan

Berdasarkan data yang ditunjukan pada tabel 1 kemudian dilakukan proses pemodelan 3 (tiga) dimensi stabilizer bar menggunakan software solidworks. Langkah pertama dalam pemodelan stabilizer bar adalah membuat sketsa tiga dimensi dengan cara menggambar titik koordinat terlebih dahulu berdasarkan data yang ditunjukkan pada tabel 1. Gambar titik yang sudah digambar dihubungkan satu-persatu dengan garis menggunakan fitur "polyline" dan setiap ujung garis yang tehubung dibuat lekukan dengan radius berdasarkan data pada tabel 1. Langkah selanjutnya membuat lingkaran pada salah satu ujung garis dengan diameter sebesar $23 \mathrm{~mm}$ (berdasarkan pengukuran), lingkaran harus digambar tegak lurus terhadap ujung garis. Langkah terakhir gunakan fitur "sweep" untuk mengubah garis sketsa dan lingkaran menjadi bentuk tiga dimensi dengan hasil akhir sperti ditunjukkan pada Gambar 4. 


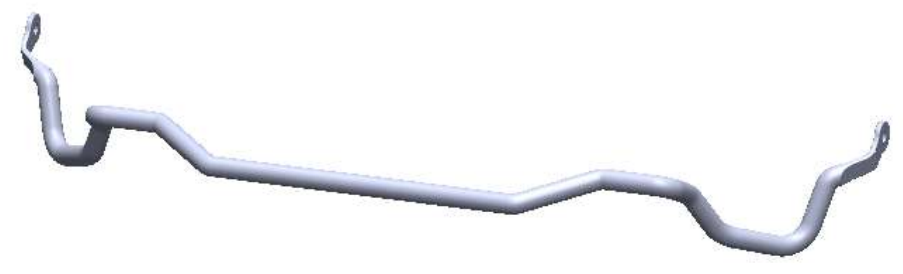

Gambar 4. Hasil Rekonstruksi Ulang Model Stabilizer Bar

Untuk memudahkan perhitungan secara manual mencari tegangan geser yang terjadi pada stabilizer bar, maka dibuat penyederhanaan model stabilizer bar yang kemudian digambarkan sebagai diagram benda bebas. Gambar 5 memperlihatkan penyederhanaan model stabilizer bar yang mengalami defleksi dan pembebanan, dan Tabel 3 menunjukan data defleksi stabilizer bar dan sudut body roll. Untuk memperoleh pemodelan safety of factor berdasarkan pembebanan pada stabilizer bar menggunakan software solidworks, diperlukan data material seperti yang ditunjukan pada Tabel 2.

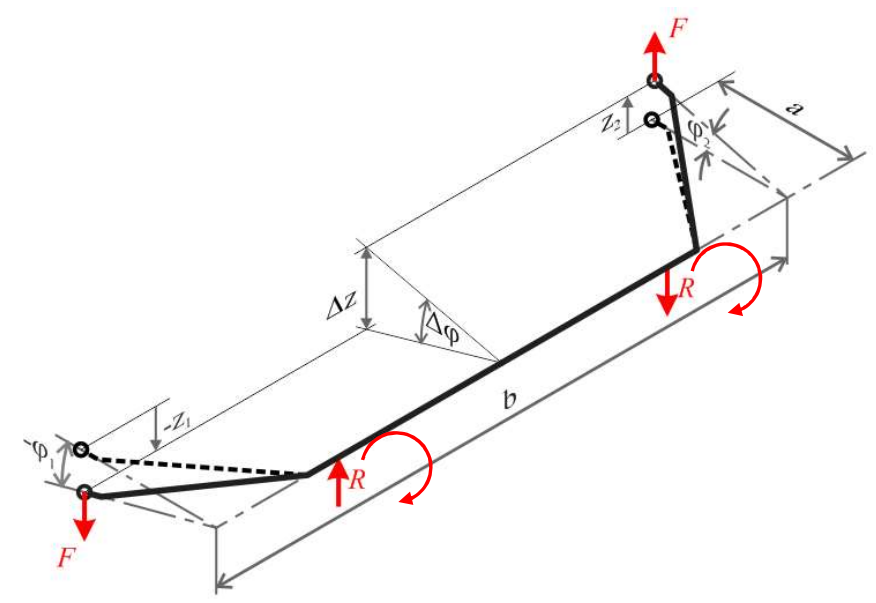

Gambar 5. Gaya Pada Stabilzier Bar Ketika Terdefleksi

dimana,

F gaya pada ujung stabilizer bar

$\mathrm{Z}_{1} \quad$ besar defleksi ujung stabilizer bar sisi kiri

[N]

$\mathrm{Z}_{2} \quad$ besar defleksi unjung stabilizer bar sisi kanan

$[\mathrm{m}]$

$\Delta \mathrm{z} \quad$ selisih defleksi kedua ujung stabilizer bar

[m]

$\varphi_{1} \quad$ besar defleksi sudut puntir stabilizer bar sisi kiri

$[\mathrm{m}]$

$\varphi_{2}$ besar defleksi sudut puntir stabilizer bar sisi kanan

$\left[{ }^{\circ}\right.$ atau radian $]$

$\left[{ }^{\circ}\right.$ atau radian $]$

$\Delta \varphi \quad$ selisih defleksi sudut puntir

a panjang lengan stabilizer bar

$\left[{ }^{\circ}\right.$ atau radian $]$

b panjang bentang stabilizer bar

[m]

$[\mathrm{m}]$

Tabel 2. Material SAE 5160

\begin{tabular}{cccc}
\hline$\sigma_{\text {yield }}(\mathrm{MPa})$ & $\tau_{\text {yield }}(\mathrm{MPa})$ & $\begin{array}{c}\text { Modulus Elastisitas, E } \\
(\mathrm{GPa})\end{array}$ & $\begin{array}{c}\text { Modulus Geser, G } \\
(\mathrm{GPa})\end{array}$ \\
\hline 985 & 492,5 & 185 & 80 \\
\hline
\end{tabular}


Tabel 3. Data Defleksi Stabilizer Bar dan Sudut Body Roll

\begin{tabular}{cccccc}
\hline Jumlah kayu & $\mathrm{S}$ & $\Delta \mathrm{z}$ & $\Delta \phi$ & $\Delta \varphi=\Delta \mathrm{z} / \mathrm{a}$ & $\Delta \varphi$ \\
\hline 0 & $0 \mathrm{~mm}$ & $0 \mathrm{~mm}$ & $0^{\circ}$ & $0 \mathrm{rad}$. & $0^{\circ}$ \\
\hline 2 & $34 \mathrm{~mm}$ & $4 \mathrm{~mm}$ & $0.46^{\circ}$ & $0,017 \mathrm{rad}$. & $0.95^{\circ}$ \\
\hline 3 & $51 \mathrm{~mm}$ & $5.5 \mathrm{~mm}$ & $1.12^{\circ}$ & $0,023 \mathrm{rad}$. & $1.31^{\circ}$ \\
\hline 4 & $68 \mathrm{~mm}$ & $7 \mathrm{~mm}$ & $1.70^{\circ}$ & $0,029 \mathrm{rad}$. & $1.67^{\circ}$ \\
\hline 5 & $85 \mathrm{~mm}$ & $8 \mathrm{~mm}$ & $2.29^{\circ}$ & $0,033 \mathrm{rad}$. & $1.91^{\circ}$ \\
\hline 6 & $102 \mathrm{~mm}$ & $9 \mathrm{~mm}$ & $2.80^{\circ}$ & $0,037 \mathrm{rad}$. & $2.14^{\circ}$ \\
\hline 7 & $119 \mathrm{~mm}$ & $10 \mathrm{~mm}$ & $3.19^{\circ}$ & $0,041 \mathrm{rad}$. & $2.39^{\circ}$ \\
\hline 8 & $136 \mathrm{~mm}$ & $11 \mathrm{~mm}$ & $3.51^{\circ}$ & $0,046 \mathrm{rad}$. & $2.62^{\circ}$ \\
\hline
\end{tabular}

Catatan: $\mathrm{a}=240 \mathrm{~mm}$

dimana,

$\begin{array}{lll}\mathrm{s} & \text { perpindahan vertikal suspensi } & {[\mathrm{mm}]} \\ \Delta \mathrm{z} & \text { defleksi stabilizer bar } & {[\mathrm{mm}]} \\ \Delta \phi & \text { sudut } \text { body roll } & {\left[{ }^{\circ} \text { atau radian }\right]} \\ \Delta \varphi & \text { sudut puntir } & {\left[{ }^{\circ} \text { atau radian }\right]}\end{array}$

\subsection{Analisis perhitungan manual}

Gambar 6 menunjukkan stabilizer bar sebagai diagram benda bebas dengan kondisi pembebanan pada ujung stabilizer bar dengan arah yang berlawanan. Sebuah segmen diambil sebagai sebuah benda bebas dari potongan bidang a-a, seperti yang terlihat dalam Gambar 7. Kemudian dari masing-masing elemen dari sistem gaya tersebut dapat ditinjau secara terpisah.

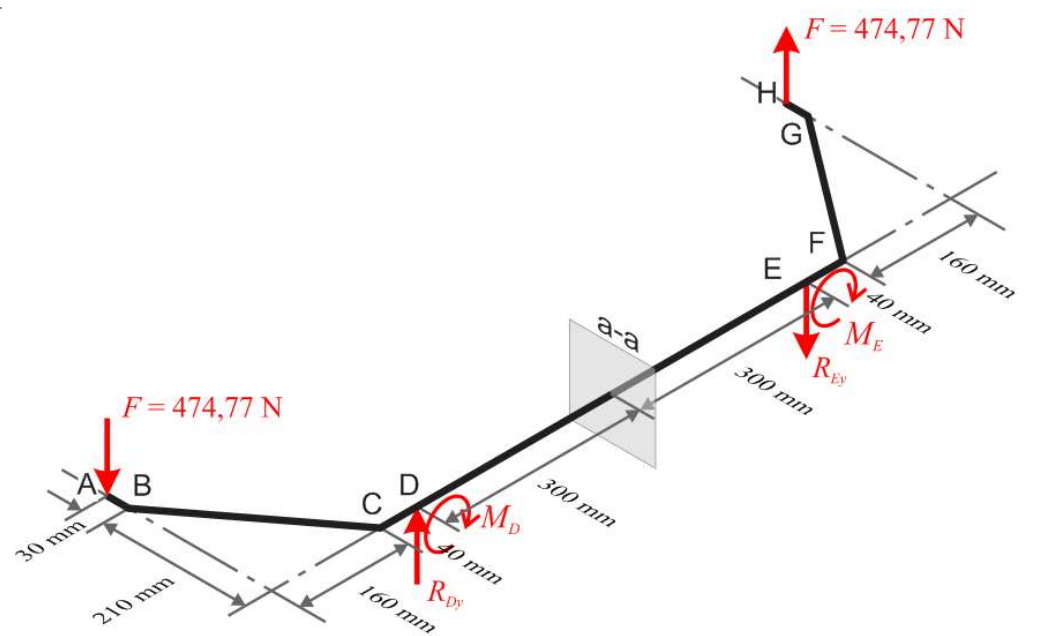

Gambar 6. Diagram Benda Bebas Stabilizer Bar

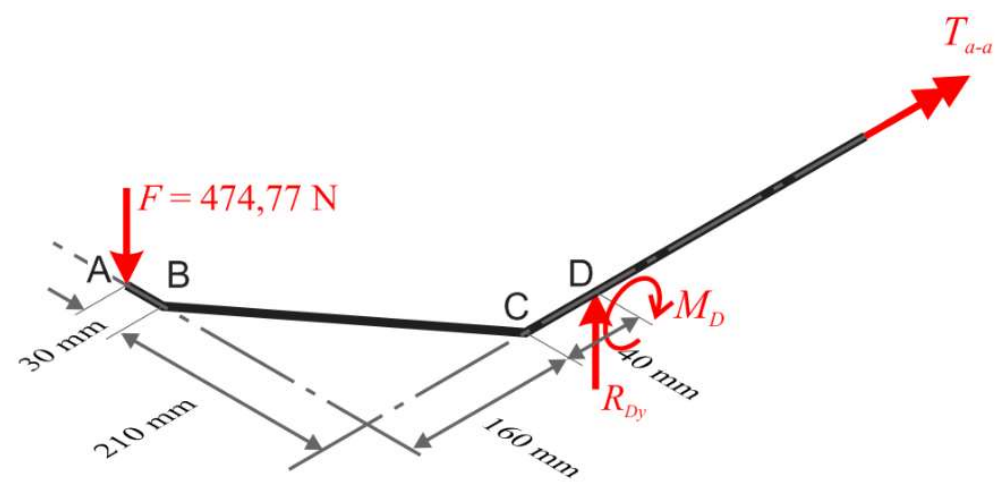

Gambar 7. Segmen Potongan Bidang a-a 


\subsection{Gaya beban pada ujung stabilizer bar $(F)$}

SAE menyajikan informasi umum tentang batang torsi dan proses pembuatannya dalam "Spring Design Manual" [5]. Stabilizer bar dibahas sebagai sub-kelompok batang torsi. Beberapa rumus yang berguna untuk menghitung kekakuan pada stabilizer bar dan defleksi pada titik akhir batang di bawah beban yang diberikan disediakan dalam manual. Geometri yang berlaku ditunjukkan pada Gambar 8 yang telah dilakukan modifikasi notasi.

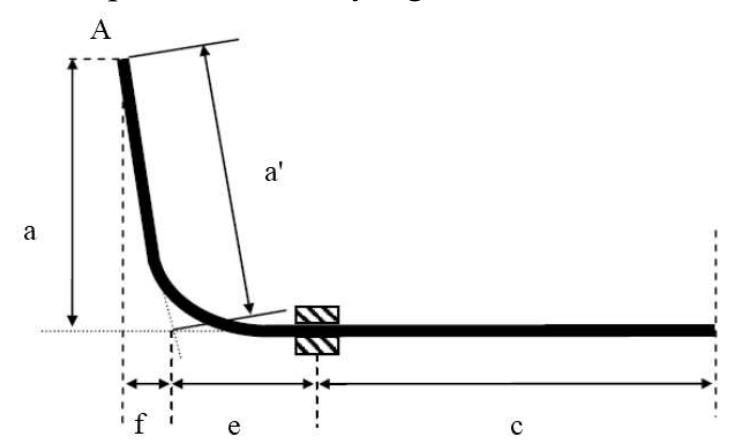

Gambar 8. Geometri Stabilizer Bar yang Digunakan di SAE Spring Design Manual (Sumber: SAE, 1996)

$$
\begin{aligned}
& L=\frac{b}{2}=c+e+\mathrm{f} \\
& F=\frac{\Delta z \cdot 3 E I}{\left[\mathrm{a}^{3}-\mathrm{f}^{3}+\frac{L}{2}(\mathrm{f}+e)^{2}+4 \mathrm{a}^{\prime 2}(e+c)\right]} \\
& F=474,77 N
\end{aligned}
$$

\subsection{Tegangan geser dan lentur}

Dari diagram benda bebas yang ditunjukkan pada Gambar 7 dilakukan pemisahan setiap batang untuk mengidentifikasi gaya, momen lentur, dan momen puntir yang terjadi seperti pada Gambar 9.

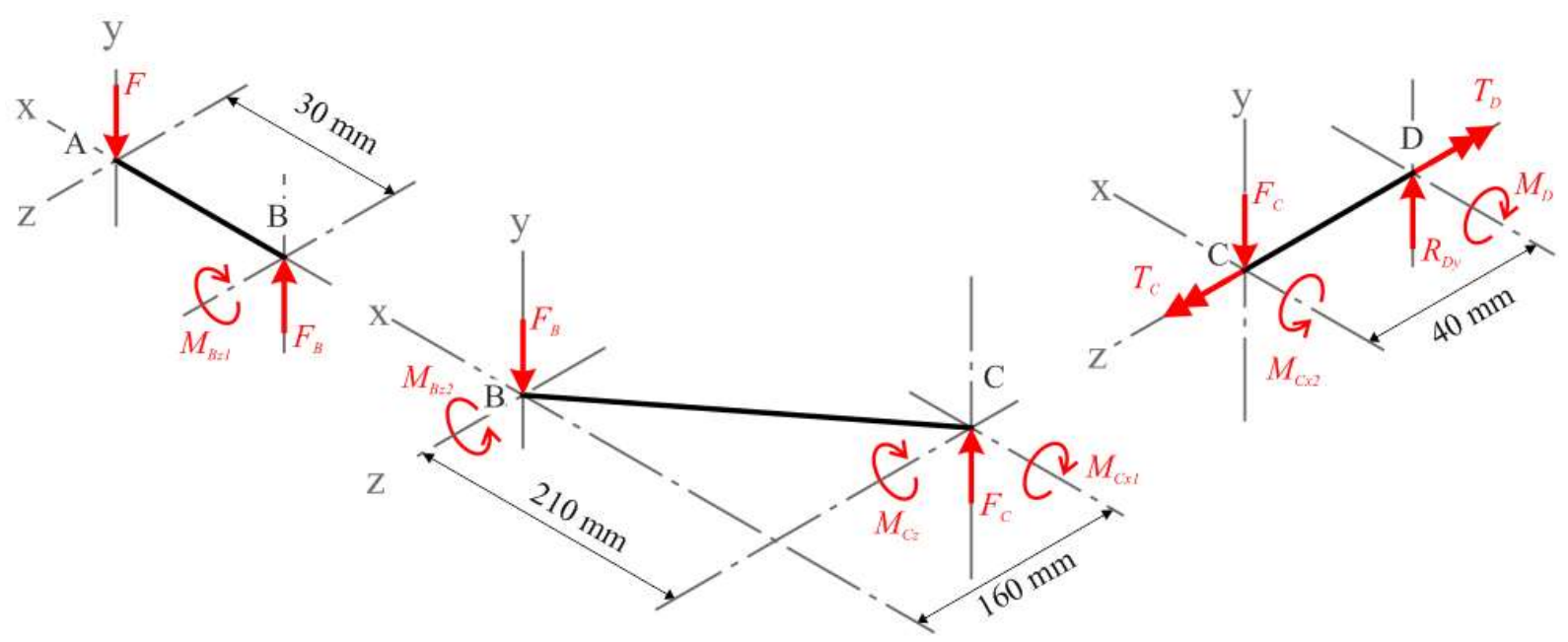

Gambar 9. Diagram Benda Bebas yang Telah Dipisah 


\subsection{Tegangan geser $(\tau)$}
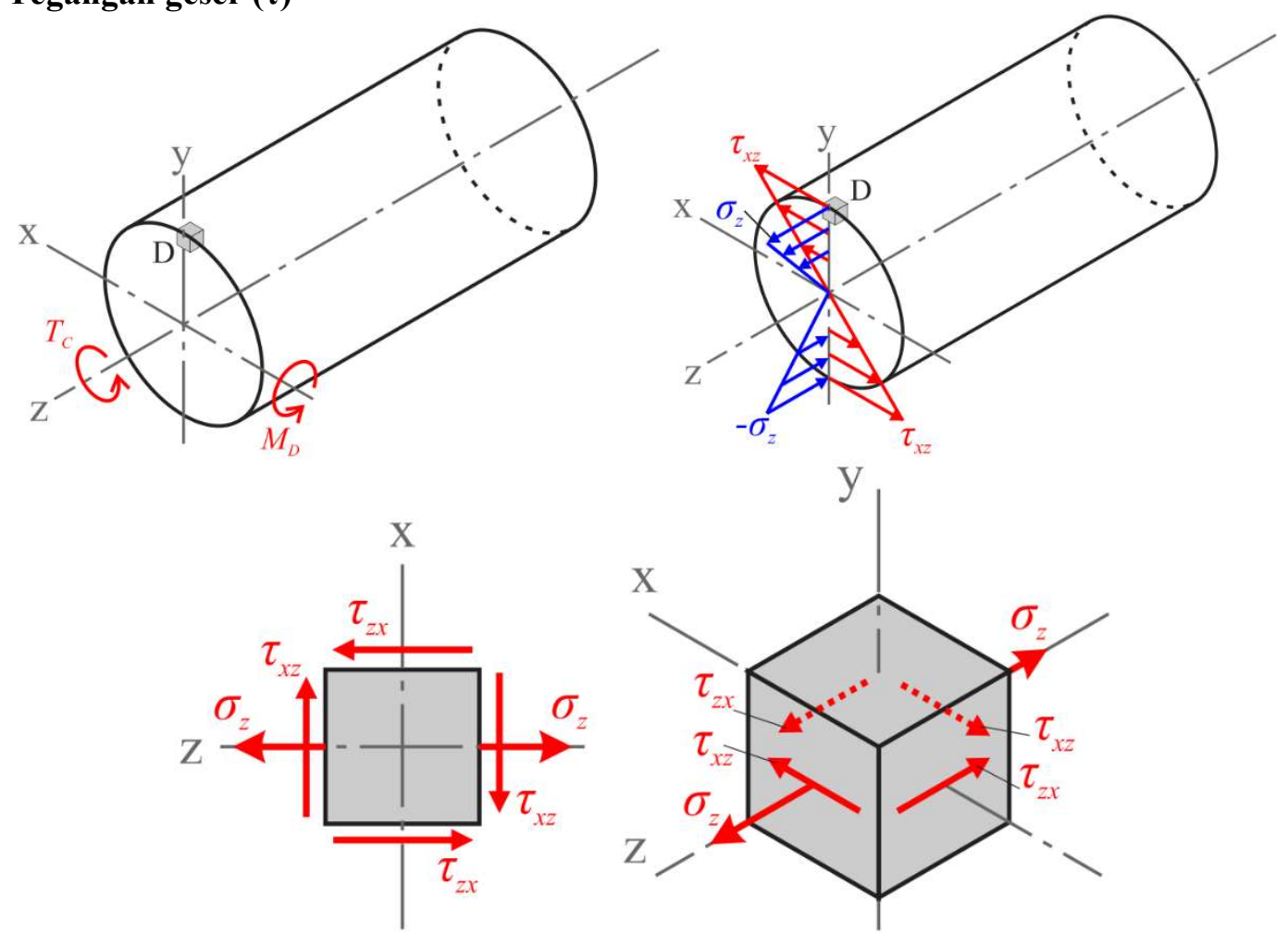

Gambar 10. Elemen Pada Titik D

Gambar 10 menunjukkan tegangan elemen pada titik D, tegangan lentur yang terjadi adalah tarik dengan besar,

$$
\begin{aligned}
& \sigma_{z}=\frac{M_{D} \cdot c}{I_{z z}} \\
& \sigma_{z} \approx 83,47 \mathrm{MPa}
\end{aligned}
$$

Momen puntir pada elemen D adalah,

$$
\begin{aligned}
\tau_{x z} & =\frac{T_{c} \cdot c}{I_{p}} \\
\tau_{x z} & \approx 31,80 \mathrm{MPa}
\end{aligned}
$$

Tegangan geser maksimum secara numerik adalah sama dengan radius lingkaran [6] yang ditunjukkan pada Gambar 11, dengan besar

$$
\begin{aligned}
\tau_{\text {max }} & =\sqrt{\left(\frac{\sigma_{x}-\sigma_{z}}{2}\right)^{2}+\tau_{x z}{ }^{2}} \\
\tau_{\text {max }} & =52,47 \mathrm{MPa}
\end{aligned}
$$




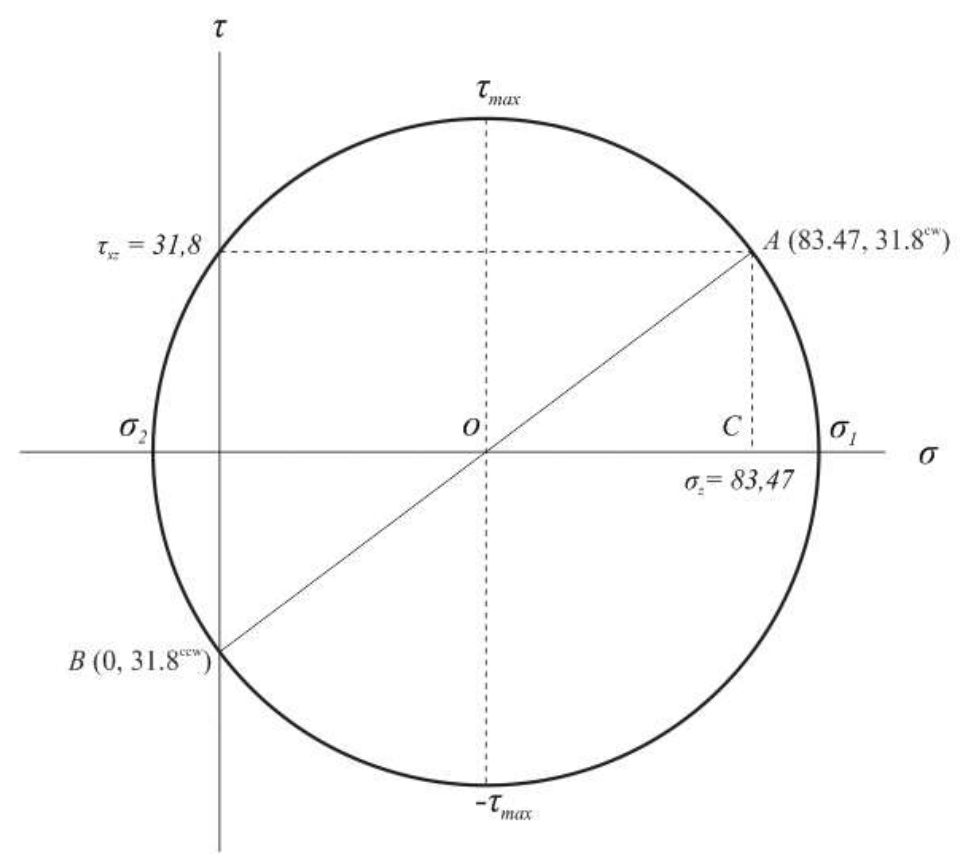

Gambar 31. Diagram Lingkaran Tegangan Mohr

\subsection{Tegangan geser beban dinamis}

ASME menganjurkan faktor koreksi untuk beban dinamis untuk beban yang terjadi sedikit kejutan atau tumbukan sebesar 1,5-3,0 [7]. Faktor koreksi ini dilambangkan $f_{d}$. Dipilih faktor koreksi 2,0.

$$
\begin{aligned}
& F=474,77 N \times f_{d} \\
& F=474,77 N \times 2 \\
& \tau_{d \text { max }}=104,94 \mathrm{MPa}
\end{aligned}
$$

\subsection{Safety Factor $(S F)$}

Sebelum mencari safety factor, perlu diketahui terlebih dahulu tegangan geser yang diizinkan dari data material yang ditunjukkan pada Tabel 2, Diperoleh besar $\tau_{\text {yield }}=492,5 \mathrm{MPa}$ $S F=9,39$

Untuk faktor kemanan ketika stabilizer bar mengalami beban dinamis, $S F_{d}=4,69$

\subsection{Hasil Simulasi Menggunakan Solidworks}

Simulasi dilakukan menggunakan software solidworks simulation dengan pengaturan sebagai berikut: (1) Mesh Density fine, (2) Mesh Parameter = Standard mesh, (3) Fixtures = Fixed hinge, (4) External loads $=$ Force 474.77 N, (5) Result $=$ Shear stress, dan factor of safety. Pada Gambar 12 dan Gambar 13 merupakan hasil analisis pada stabilizer bar dalam kondisi statis menghasilkan data sebagai berikut:

- Tegangan geser maksimum

- Safety of Factor

$$
\begin{aligned}
& =50,05 \mathrm{Mpa} \\
& =8,96
\end{aligned}
$$



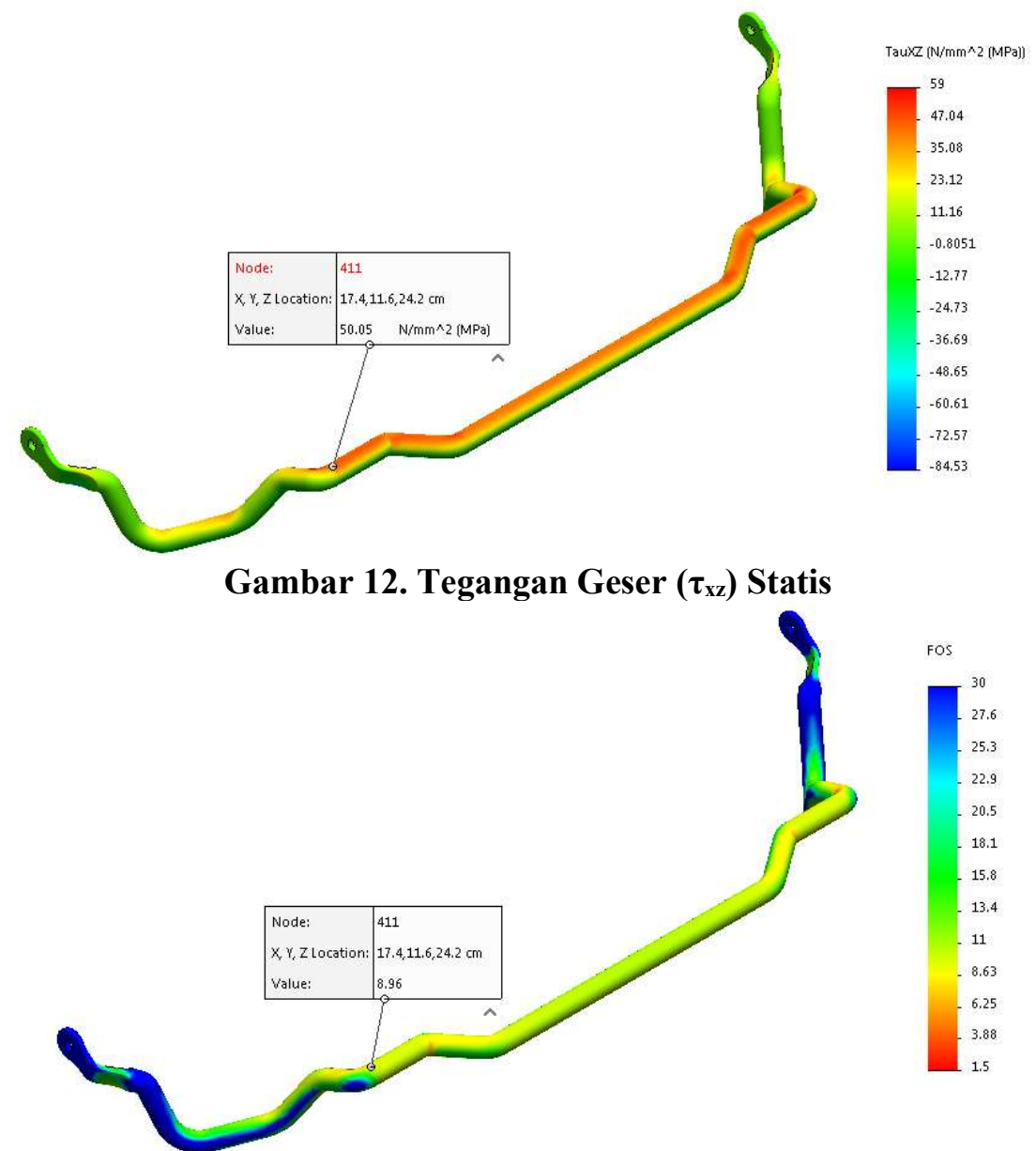

\section{Gambar 13. Safety of Factor Statis}

Pada Gambar 14 dan Gambar 15 merupakan hasil analisis pada stabilizer bar dalam kondisi dinamis menghasilkan data sebagai berikut:
- $\quad$ Tegangan geser maksimum
$=100,1 \mathrm{Mpa}$
- Safety of Factor
$=4,48$

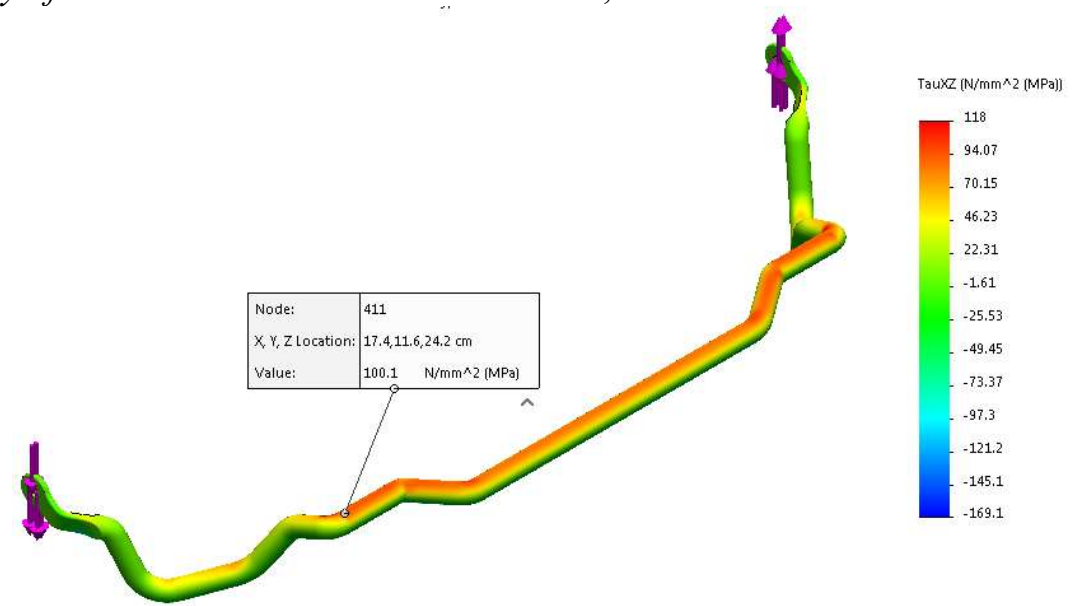

Gambar 44. Tegangan Geser $\left(\tau_{\mathrm{xz}}\right)$ Dinamis 


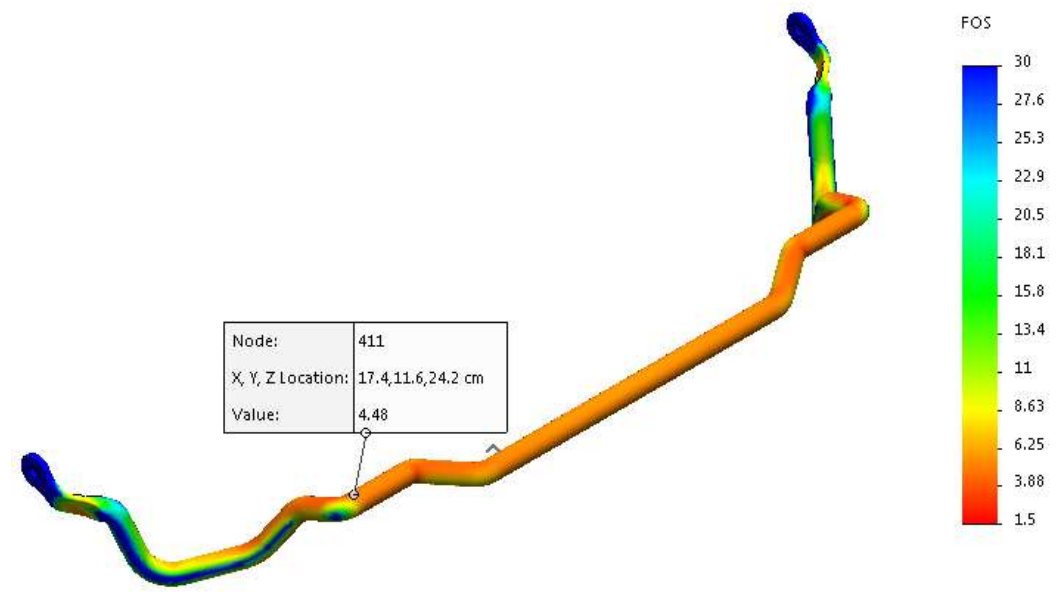

Gambar 15. Safety of Factor Dinamis

\subsection{Korelasi Tegangan Geser dengan Sudut Body Roll}

Untuk mengetahui korelasi tegangan geser dengan sudut body roll, dapat dilakukan dengan fasilitas regresi linier di Microsoft Excel [8]. Cara nya dengan mengaktifkan terlebih dahulu plugin addins analysis data. Setelah ditambahkan, plugins tersebut, dapat dilakukan analisis regresi linier pada masing-masing sampel berdasarkan data pada Tabel 3.

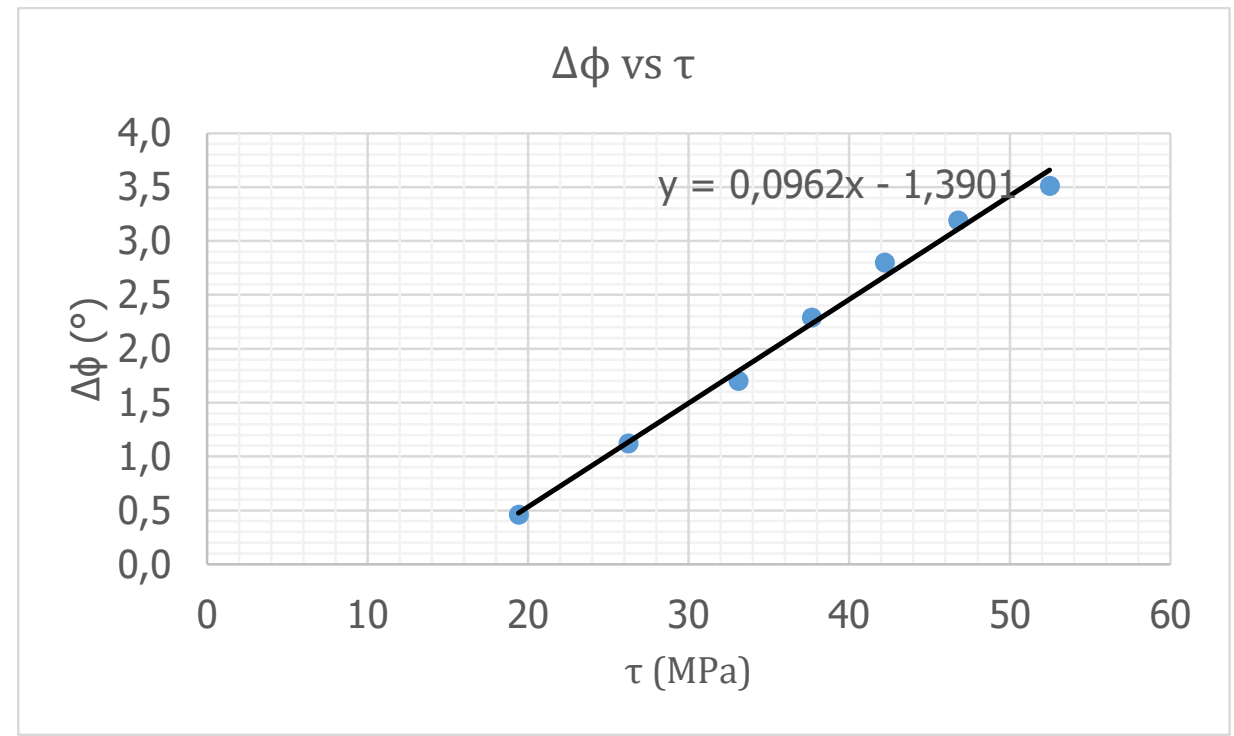

Gambar 56. Grafik Regresi Linier

Berdasarkan data yang ditampilkan pada Gambar 16 terdapat persamaan fungsi regresi linier $\mathrm{y}=0,0962 \mathrm{x}-1,3901$, dimana $\mathrm{y}=\Delta \phi$ dan $\mathrm{x}=\tau$. Maka dari persamaan tersebut dapat diprediksi berapa besar sudut body roll kritis ketika stabilizer bar mulai mengalami deformasi plastis.

$$
\begin{aligned}
& \Delta \phi=0,0962 \tau-1,3901 \\
& \Delta \phi=45,99^{\circ}
\end{aligned}
$$

\section{Kesimpulan}

Dari hasil analisis kekuatan stabilizer bar (anti-roll bar) pada kendaraan roda empat dapat diambil beberapa kesimpulan, antara lain ketika kendaraan dalam kondisi statis dimana mengalami body roll sebesar $3,51^{\circ}$, Stabilizer bar mengalami tegangan geser dari hasil perhitungan manual sebesar 52,47 MPa dan faktor keamanan sebesar 9,39. Pada ujung stabilizer bar diketahui gaya yang 
diterima oleh stabilizer bar sebesar 474,77 $\mathrm{N}$ dalam kondisi statis. Tegangan geser yang terjadi dan faktor keamanan dari hasil analisa menggunakan software solidwork dalam kondisi statis sebesar 50,05 MPa dan 8,96. Tegangan geser dan faktor keamanan stabilizer bar dalam kondisi dinamis dengan memberikan faktor koreksi sebesar 2,0 adalah 104,94 MPa dan 4,69. Tegangan geser yang terjadi dan faktor keamanan dari hasil analisa menggunakan software solidwork dalam kondisi dinamis sebesar 100,1 MPa dan 4,48. Besarnya sudut body roll ketika stabilizer bar mulai mengalami deformasi plastis dapat diprediksi menggunakan persamaan regresi linier yang dihasilkan dari korelasi antara sudut body roll dan tegangan geser, yaitu sudut body roll yang dapat dicapai sebesar $45,99^{\circ}$.

\section{Daftar Pustaka}

[1] Uys, P., Els, P., \& Thoresson, M. (2006). Criteria for Handling Measurement. Journal of Terramechanics, 43:43-67.

[2] Parczewski, K., \& Wnek, H. (2017). The Influence of Vehicle Body Roll Angle on The Motion Stability and Maneuverability of The Vehicle. Diambil kembali dari Combustion Engines.

[3] Hari Setiawan, Arif. (2013). Analisa Kesetabilan Guling Kendaraan Jalan 4 Roda Dengan Pendekatan Chasis Elastis, Tesis, Institut Teknologi Sepeluh Nopember Surabaya.

[4] Abunaim, Teguh Budi S. (2009). Kaji Pengaruh Anti-Roll Bar Pada Suspensi Independen depan Kendaraan ATV Z200 Terhadap Perilaku Body Roll. Jurnal Rekayasa Mesin. Vol. 9 no.1. 12-17.

[5] Spring Design Manual. (1996). SAE Spring Committee, 215-267.

[6] Popov, E. P. (1984). Mekanika Teknik(Vol. 2). (Z. Astamar, Penerj.) Jakarta: Erlangga.

[7] Sularso, \& Suga, K. (2004). Dasar Perancangan Dan Pemilihan Elemen Mesin. Jakarta: Pradnya Paramita.

[8] Carlberg Conrad, (2018), Predictive Analytics: Microsoft Excel, -, edisi 2, Pearson, Indianapolis USA. 